\title{
The quality of dwellings in the Romanian Danube Valley
}

\author{
Irena Mocanu, Bianca Mitricã*, Nicoleta Damian, \\ Mihaela Rodica Persu
}

Institute of Geography, Romania

The quality of dwelling, one of the main components of the urban and rural living conditions, is the result of political, legislative, economic, demographic contexts. The present paper approaches the complex issues of dwelling quality in the Romanian Danube Valley, based on the territorial disparities (LAU2 level) of three types of statistical indicators: dwelling stock (\% of finished dwellings, \% of finished dwellings out of the total number of dwellings), dwelling development indicators (living floor/m2 dwelling, living floor m2/inhabitant, density of dwellings) and comfort indicators (access to drinking water, sewerage, electricity, etc.). Differences in the Danube Valley dwelling quality are revealed by the Dwelling Quality Index (DQI).

Key Words: quality of dwellings, Romanian Danube Valley, territorial disparities.

Article Info: Received: December 22, 2017; Revised: April 19, 2017; Accepted: May 5, 2017; Online: May 25, 2017.

\section{Introduction}

Housing implies a complexity of socio-economic activities connected with it directly or indirectly: transport infrastructure, technical-urbanistic endowments and socio-cultural services characteristics and quality of the dwelling-house, and no less the surrounding environment.

The broad field of housing and dwellings is diverse and complex and it is under the guiding principles for sustainable territorial development at continental and regional level, the legal aspects and access to habitation representing a topic for some Romanian studies (e.g. Dan, 2003, 2005, Zamfir, Preda, Dan,

\footnotetext{
* Corresponding author

Address: Institute of Geography, Romanian Academy, D. Racovita Street, no. 12, 023993, Bucharest, Romania.

Phone: +40213135990 | Email: biancadumitrescu78@yahoo.com
}

(C)2017 Human Geographies; The authors

(c) (i) This work is licensed under a

Creative Commons Attribution 4.0 International License. DOI:10.5719/hgeo.2017.111.6 
2004). Dwellings, as a basic component of habitation (Alpopi, 2007, Ministry of Regional Development and Public Administration, 2013), it takes, reflects and influences these distinctions recorded by the housing situation in Western and Eastern European countries. Dwelling represents the physical manifestation and the occupation of a structure (dwelling unit), habitation including procedural, corrective-interventionst elements, housing security, as well as other nonmaterial aspects (ONU, Comment No. 4, 1991, quoted by Dan, 2005, p. 6). Dwellings reflect the economic, cultural, historical, legal, demographic and physical-geographical characteristics of a community and its geographical environment. The dwelling-place, a combination of all these elements, is emblematic for a family's social status (Damian, 2013).

The economic context puts a deep imprint on the dwellings characteristics. For example, during the financial crisis, the housing inequalities and social classes became topic for some studies. The most pressing issue of the economic crisis is raising unemployment but also households in which a bread-winner becomes unemployed face a significant decline in earnings (Fondeville and Ward, 2009, Heathcote et al., 2010).

More recently, the problems related to housing wealth and inequality are debated in papers which conducted a comparative analysis of housing conditions in different European countries by focussing on social class (Filandri and Olagnero, 2014) and an explanation of the paradox (that home ownership does not exclude housing deprivation) which characterised the housing conditions in Europe over the last three decades (Olagnero and Filandri, 2014).

The housing situation in Europe differs greatly between Western European countries and former communist countries in Eastern Europe, both in terms of quantity and quality (Kabisch and Grossmann, 2013). An extensive analysis of the housing situation at national level (Alpopi et al., 2014) is important in relation to other EU countries and also in terms of indicators used (e.g. the number of dwellings/1000 inhabitants, the average number of rooms/dwelling, overcrowding).

Geographers have used specific methods to study problems of housing and of dwellings at local and regional level. The dwelling quality was approached in complex geographical studies. the issues of housing and dwelling quality were approached in comprehensive study of the Romanian Danube Valley (Ianoş, 2000). Vîrdol (2008) highlighted the importance of dwelling-houses for the development level of Romanian towns and Vîrdol (2009) adressed different aspects of dwelling quality in small Danubian towns. Vîrdol et al. (2015) approached the main features of the dynamics of the Romanian housing stock in various morphological categories, as one of the indicators used to express the state of the economy. The study published by Vâlceanu, Tămârjan (2011) is focused on diagnosis of housing conditions in post-adhering to European Union, highlighting the precariousness of housing quality, as the main element of the quality of life. Vâlceanu and Zulaica (2012) have used Housing Quality Index (HQI) as analysis tool of urban housing and its assessment of the quality, the statistical analysis being correlated with social research methods and territorial identification of the main failures of housing contributing to the urban zoning areas. Gavriş (2011) analyses the major urban habitats of Bucharest in terms of their homogeneity, their internal structure (including the study of 


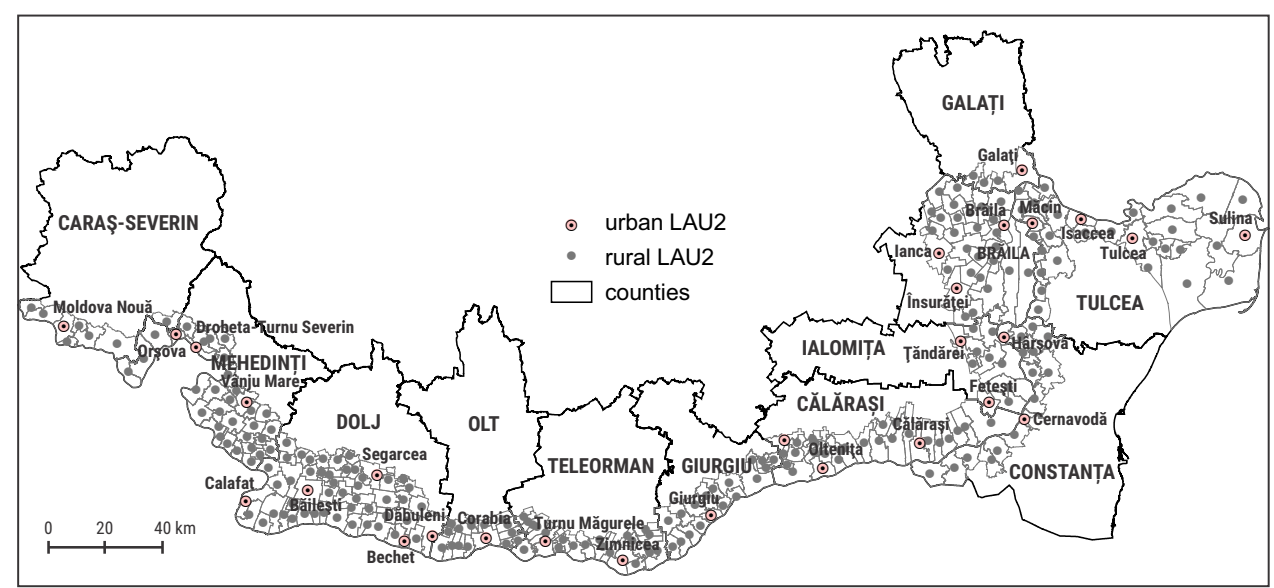

Figure 1. The Romanian Danube Valley - urban and rural local-administrative units

residential areas), their dynamics and their integration into the macro-structure represented by the Capital City. Antonescu (2014) approached housing as a fundamental aspect of modern society, an indicator of standard of living and prosperity. Among the various core areas considered in studies about quality of urban life are those focussed on the quality of the built environment (Nae, 2006 and 2009). The Priority Research Project of the Romanian Academy, The Geographical Study of the Romanian Danube Valley includes dwelling quality issues, emphasissed the following aspects: the factors influencing the quality of dwellings-houses, the inadequate housing conditions in terms of endwement infrastructure and the linkage between ethnic diversity and dwelling quality (IGAR, 2015).

Housing quality covers a wide range of aspects, but this study is focused on the quality of dwellings, meaning that the quality elements are related to dwelling itself. The availability of statistical data at local administrative territorial level represented the main factor which restricted the geographical approach of dwellings' quality in Romanian Danube Valley. Thus, in this study, the quality of dwellings is reflected by the overcrowding and houses deprivation.

\section{Study-area}

The Romanian Danube Valley is an integrated part of the Danube Region. The EU Strategy for the Danube Region (EUSDR), a macro-regional strategy adopted by the European Commission in December 2010, provides a sustainable framework for policy integration and coherent development of the ter ritory covered; it sets out priority actions to make it an EU region for the 21 st century (http://www.danube-region.eu). The Danube Region covers 14 countries (eight of them EU Member States) and is home to more 100 million people, a fifth of the EU's population) (COM(2013) 181).

The Romanian sector of the Danube Valley covers a large area, in which the life of resident communities is shaped by the River long 1,075 km (Figure 1). The Danube Valley is one of the oldest Romanian territories steadily inhabited by a sedentary population (1,7 million today) ever since the Palaeolithic Times (Romania. Historical-Geographical Atlas, 2007). 
In Romania, four development regions and twelve counties (with 235 rural local-administrative units and 28 urban local-administrative units-LAU2) are crossed by the Danube River.

From times immemorial the Romanian Danube Valley has been a good place for human settlement, beneficial to economic activities. Thus, the Valley area has a large number of rural settlements, but also towns of appreciable age, human and economic potential. Over the past 26 years, the dwellings from Romanian Danube Valley territory, like all of the rural and urban living conditions, have been deeply marked by various historic, socio-economic and legislative experiences. The dwelling stock is overwhelmingly private property. Public investments in urban housing, made in the 1950-1989 period, were very much reduced after 1990. The life-time of significant number of dwellings, most of them collective town residences, has expired (or is close to) (Strategia de dezvoltare teritorială a României, 2014).

This paper aims to address the quality issue of dwellings by the empirical examination of two different and dependent research directions: firstly, to identify the statistical variables and indicators available for local administrative units (LAU2) to measure the quality of dwelling-houses and secondly, to assess the quality of dwellings in the Romanian Danube Valley. The first section approaches aspects of data-sources and methods. The study relies on the data provided by the National Institute of Statistics, the results of the Population and Housing Census, 2011 and TEMPO Online, processed and mapped for computing the Dwelling Quality Index (DQI). The level of dwelling quality is determined, analysed and mapped.

\section{Material and method}

The present study resorts to statistical data of the Romanian Danube Valley local administrative units (LAU2), found in TEMPO-Online data-base and in the Population and Housing Census (October, 2011). The complex aspects of dwelling quality are discussed in the light of three secondary indexes, designated by 11 primary indicators, resulted from 12 statistical variables:

1) the dwelling stock index (DSI): number of dwellings (Stockdwell), \% of finished dwellings/total number of dwellings (\%Finishdwell);

2) the dwelling development index (DDI): density of dwellings (number of dwellings/km2 - Densitydwell), living floor (m2)/dwelling (Livefloor/dwell), living floor (m2)/inhabitant (Livefloor/inhab.);

3) the dwelling comfort index (DCI): \% of dwellings with indoor water supply (\%Water), sewerage system (\%Sewerage), electrical installation (\%Electricity), central heating installation (\%Heating), kitchen (\% Kitchen) and bathroom (\%Bathroom).

These three secondary indexes have been computed as arithmetic mean of the standardised values of the 11 primary indicators, the dwelling quality index (DQI) being assessed as arithmetic mean of the three secondary indexes (Figure 2). Statistical variables and indicators have been chosen in terms of the data-base available at LAU2 level and the examples found in several works of sociology, geography, urbanism and architecture or of multi-disciplinary character (e.g. 


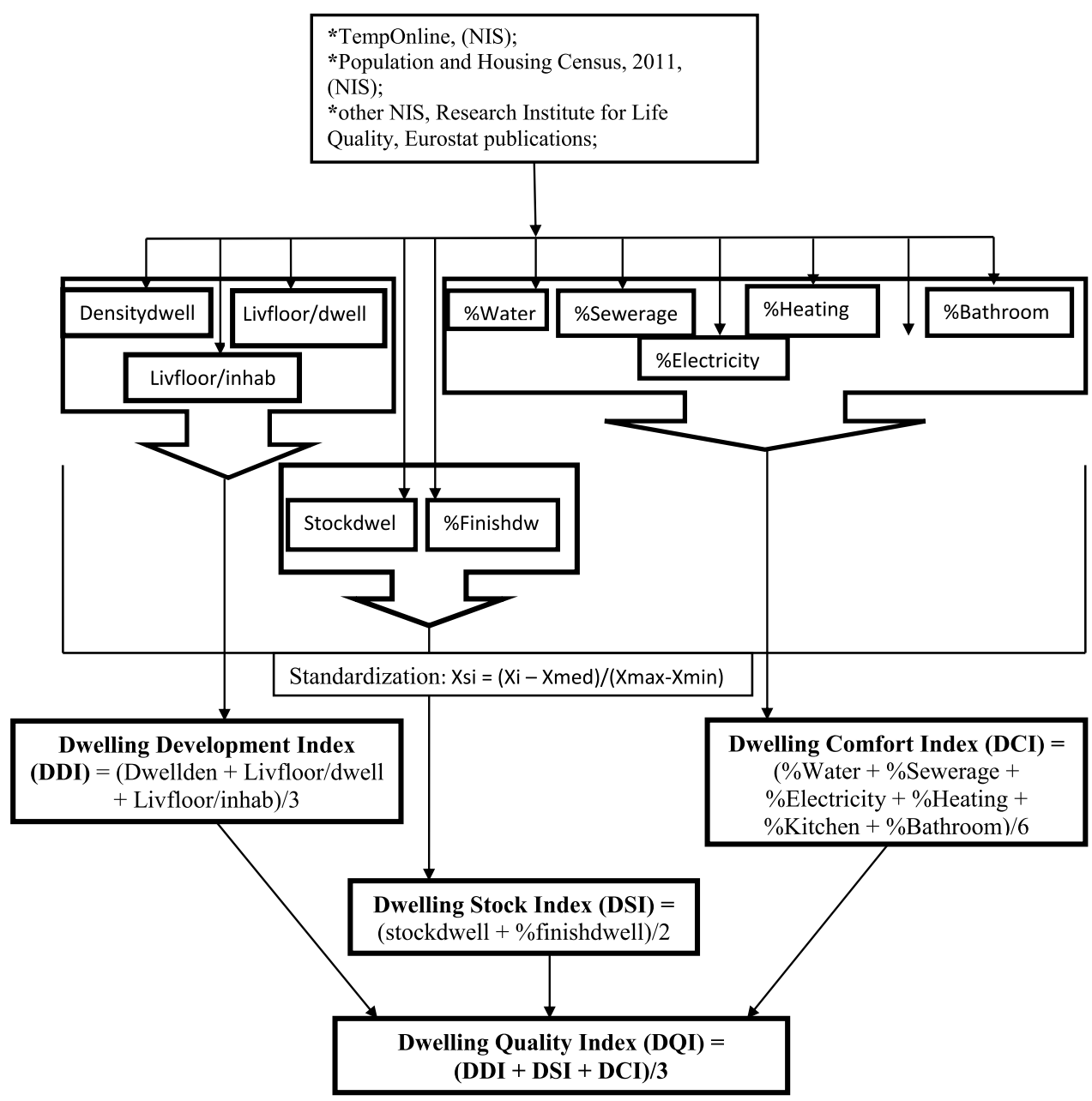

Figure 2. Index design

Dan, 2003, 2005, Vâlceanu, Tămârjan, 2011, Vâlceanu, 2012, Damian, 2013, Vîrdol et al., 2015).

The present study uses the term "dwelling" as defined in the methodology of statistical data collection for the October 2011 Population and Housing Census and in the TEMP-Online data-base: "a dwelling is the built unit made up of one or more habitable rooms situated at the same floor of the building or at different floors, generally fitted with outhouses (kitchen, bathroom) or with other serving spaces, which is functionally independent and has a separate entrance from the staircase hall, yard or street and which has been built, transformed or arranged with a view to being used, in theory, by one household" (Source: http://www.recensamantromania.ro/, https://statistici.insse.ro/).

\section{Results and discussion}

The dwelling stock index (DSI) is appraised by two statistical indicators, namely, number of dwellings and \% of finished dwellings/total number of dwellings. The 


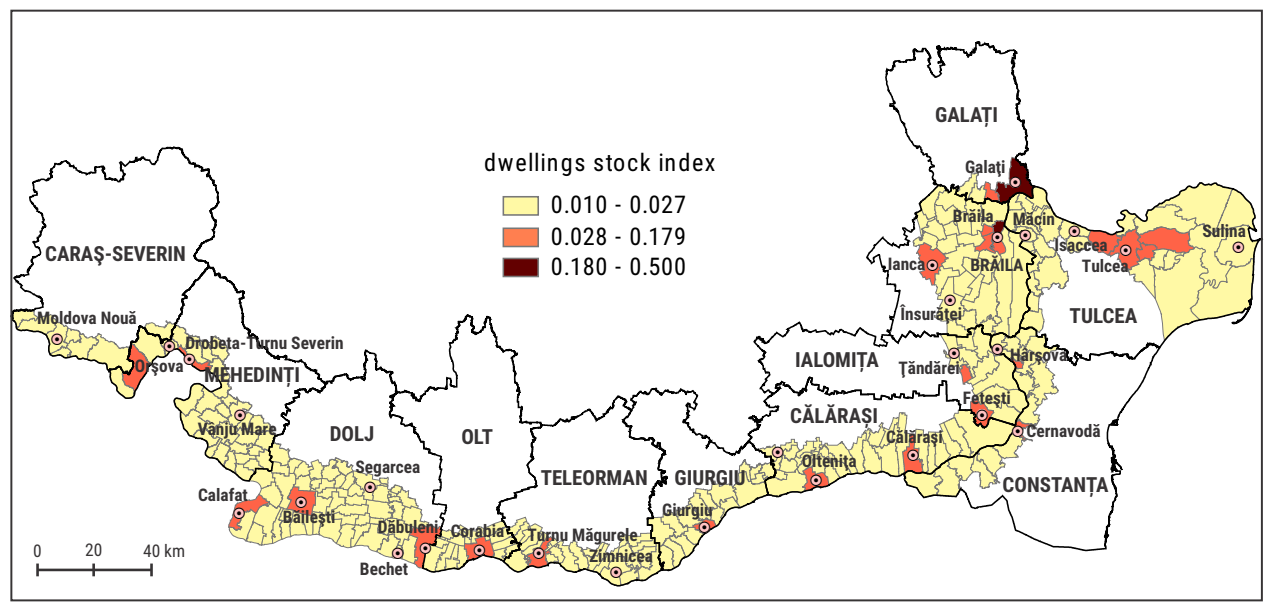

Figure 3. The dwelling stock index (DSI) - territorial disparities

Source: 2011 Population and Housing Census and TempOnline statistical data processed and mapped

Romanian Danube Valley has 885,000 dwelling-units (with 50.6\% in the rural area), which represents $10 \%$ of the total number of dwellings in Romania. Evolution over the past two decades (1992 to 2011) were largely positive, the region as a whole having 73,400 more dwellings (6.4\%). Only $20 \%$ of the Danubian settlements had a decrease record. Until 1990, the stock of dwellings increased mostly in the urban area, but after that date the Danube Valley rural area registered a significant $7 \%$ average increase. In terms of dwelling number, the 2011 Census indicates that Danubian towns and municipia fall into the high value class, with 5,001-20,000 and 120,000 dwellings.

The largest dwelling stock have the cities of Galaţi (112,669 dwellings), Brăila $(79,047)$ and Drobeta-Turnu Severin (40,334). On the opposite side are the LAU2 with under 1,000 dwellings, this class englobing over one-third of all of the Danube Valley settlemenets. Communes with fewest dwellings occur in the counties of Tulcea, Constanţa, but also in the central sector of the Valley (Teleorman and Dolj counties).

The dwelling stock index (DSI) varies widely from a minimum of 0.001 0.002 (low demographic size communes situated in isolated areas of the Danube Delta and of the Romanian Plain (especially in the Bărăgan and Oltenia Plains) and a maximum of 0.500 (Galaţi Municipium).

As expected, county capitals have the highest score, with Galaţi and Brăila (0.351) heading the hierarchy, from the third place downwards values fall sharply to 0.179 and 0.122 (Drobeta Turnu-Severin, Tulcea and Giurgiu). Some rural LAU2, situated in the neighbourhood of urban centres (e.g. Cazasu close to Brăila, Şendreni near Galaţi) have a score comparable to town, because townspeople have built themselves residential places there. Index values are the lowest in scarcely populated communes, which obviously have fewer dwellings and fewer finished dwellings. In many cases these communes register also a steep demographic fall (Figure 3). 
Very great densities (highest value classes over 2,000 dwellings/km2) have only the cities of Galaţi (2,800 dwellings/km2), Brăila (3,000 dwellings/km2), Tulcea (4,300 dwellings/km2) and Drobeta-Turnu Severin (4,000 dwellings/km2); great densities $(1,000-2,000$ dwellings/km2) have $18 \%$ of the Danubian settlements, both urban (9 towns) and rural (37 rural LAU2). Most settlements (two-thirds) fall into the low and very low class categories (500-800) and under 500 dwellings/km2, respectively). Occasionally, the low density of dewllings in the countryside could be an advantage, meaning proximity to natural and cultural areas of tourist interest (e.g. the Danube Delta), as well as favourable environmental factors. A key indicator of housing quality is the living floor (m2/person), which measures the adequacy of living space in dwellings (Millennium Development Goals Dashboard, 2014). A low value of this indicator is a sign of overcrowding, the World Health Organization establishing at least $5.5 \mathrm{~m} 2 /$ person.

The living floor/person by residential environments shows greater scarcity of dwellings in towns (18.6 m2/person) than in the country-side (20 m2/person). In the last ten years, the average living floor/person has been increasing, due especially to increases in the country-side. The largest living floor/person (over $20 \mathrm{~m} 2$ /person) have the small towns of Vânju Mare, Corabia, Sulina, Zimnicea, Moldova Nouă and Orşova, surpassing the average value of the region; similarly, more than 100 rural LAU2 register over $30 \mathrm{~m} 2 /$ person.

In the Danube Delta, the average living floor/dwelling suggests a slightly elevated general comfort versus to the all-country average $(44.8 \mathrm{~m} 2 /$ dwelling to $38.2 \mathrm{~m} 2 /$ dwelling, respectively), with $45.2 \mathrm{~m} 2 /$ dwelling in the Danubian countryside compared to $44.4 \mathrm{~m} 2 / \mathrm{dwelling}$ in towns of the area, suggesting rather smaller dwellings in the urban area. In the territory, maximum values (50-71 $\mathrm{m} 2 /$ dwelling) are found in the small towns, with fewer than 20,000 inhabitants (Zimnicea, Feteşti, Bechet, Dăbuleni, Corabia and Calafat), rural LAU2 in this category having the counties of Dolj, Olt and Teleorman counties.

Highest dwelling development index values register the small demographic size communes, with an ongoing aging process and a low natural balance (in Tulcea, Mehedinţi, Caraş-Severin, Teleorman and Dolj counties). As far as dwelling development is concerned, the elevated values of living floor per person and per dwelling suggest spacious residences, usually meeting the standards of space allotted to their occupants. However, there are many instances in which the tenants of these dwellings are one or two elderly people, because numerous localities undergo a process of demographic aging, specific to the majority of Danube Valley rural settlements, of isolated places, in particular, with little access to public utilities and to the transport infrastructure. This reality is obvious when looking at the position of these settlements at the bottom of the secondary dwelling comfort index hierarchy: elevated dwelling density, spacious residences but few tenants through ageing or migration.

Low dwelling development index values (under 0.300), specific to rural settlements in the east of the Danube Valley: Călăraşi, Ialomiţa, Brăila, Tulcea counties and only accidentely in the west of the Valley (Dolj and Mehedinţi counties) are caused by depleted and very depleted values of the living floor per dwelling and per person (Figure 4). 


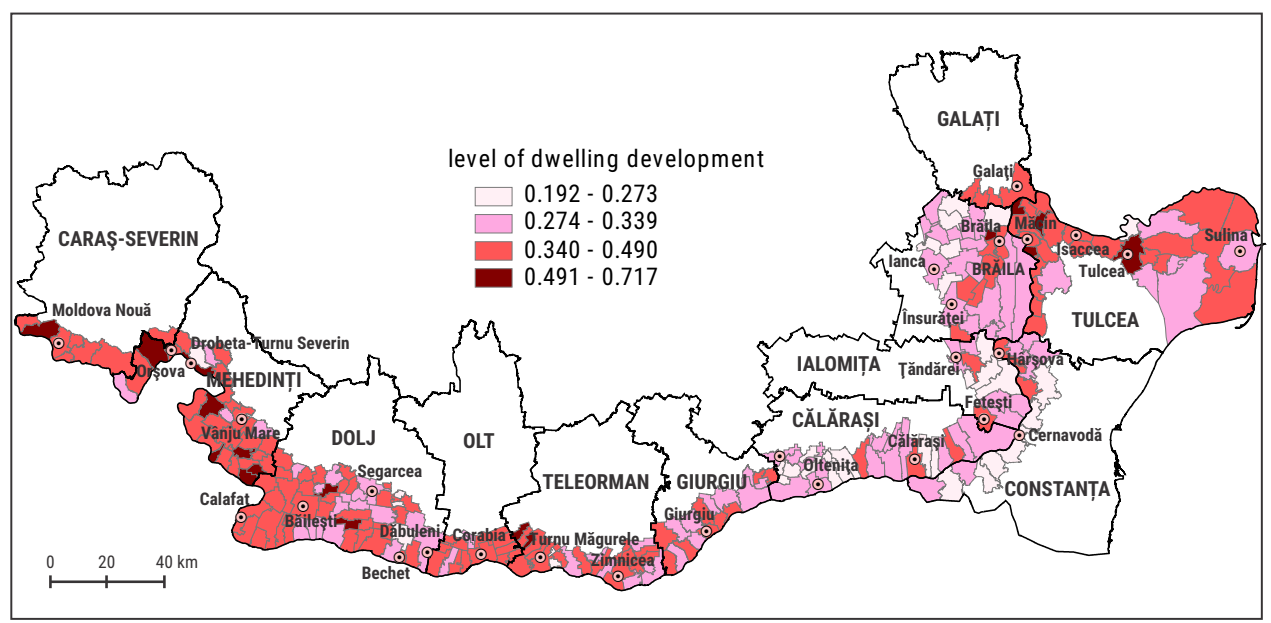

Figure 4. The dwelling development index (DDI) - territorial disparities

Source: 2011 Population and Housing Census and TempOnline statistical data processed and mapped

\section{The dwellings comfort index (DCI)}

The proportion of houses connected to the water supply and sewerage systems is between 0\% (in Olt County, 10 of its rural settlements are not connected to water supply) and 98\% (in Drobeta -Turnu Severin). In most towns, over $70 \%$ of the houses are supplied with drinking water, but there are cases in which this percentage is under $30 \%$ (e.g. Budeşti - 26\% and Însurăţei - 28.5\%). Only 35 localities, out of a total of 266 , have over $50 \%$ of the houses connected to the drinking water and sewerage systems.

The technical infrastructure is an important aspect of the assessment of housing quality. People living in accommodation without basic amenities (a bath or shower, hot running water and central heating) are considered to be affected by housing deprivation (Alpopi et al., 2014). The absence of investments in updating sewerage and drinking water installations has a negative impact on the quality of water and implicitly on people's health state. Besides, improper conditions in the waste water collection network increase water pollution, with detrimental effects on the environment.

Over $80 \%$ of the houses in the more isolated Danube Delta settlements have electricity and $98-100 \%$ in the majority of localities, an important role had and still has the creation of the modern energy system in line with EU demands, having in view that one of the 11 priority directions of the EU Danube Region Strategy is to encourage sustainable energy (Danube Region Strategy. Energy, http://groupspaces.com/Energy2). As of 2011, regulation activities have been focusing on making electrical energy markets more transparent and promote electrical energy production from renewable sources. Aeolian parks have been developed in Dobrogea, one of them close to Cernavodă Town. Propitious conditions for aeolian energy production exist also in Tulcea County; solar energy and biomass-related production of energy have Brăila and Constanţa counties. Local energy policy and planning aimed, inter alia, to stimulate the use of solar thermal systems (e.g. the results of implementing this type of local 
initiative have become visible since 2010, when numerous buildings in Giurgiu City have benefited from water-heating solar panels mounted on the roof of 380 individual and collective dwellings, Promoting Solar Thermal Ordinances Project- ProSTO, 2008-2010).

As for house heating, very few rural households have their own heating system, whether it is firewood, electric current or natural gas. The low percentage of dwellings with individual heating system is specific to the newly-built or rehabilitated residential areas, enveloped to reduce energy consumption and as much as possible losses. Most houses in town had been connected to the public thermal energy supply system, production, transport and distribution in each administrative unit. After 1997, the number of its users decreased, their owners preferring to have individual heating facilities installed in the house, which also reduced the costs. Decreases in the central-based system is largely due to the slowdown of the activity of industrial estates, which used to produce technological steam and hot water that was further distributed to town dwellings, as well as to the high production costs, low technical parameters and losses in the network.

The cartographic representation of the statistical indicator "share of houses with individual heating system" reveals that in most of the Danube Valley communes the proportion of individual central heating system facilities is very low $(0-9 \%)$. It is the case of 235 localities, basically $88 \%$ of all the Danubian settlements. The same situation have some tourist settlements (Crişan Commune in the Danube Delta - Tulcea County and Eşelniţa - Mehedinţi County), but also certain localities better developed economically or located close to town (e.g. Chişcani near Brăila, Şendreni near Galaţi). The share of houses in this category is of 10-20 percent. Also in Cazaşu Commune, close to Braila City, there are relatively numerous dwellings in this category (22\%). These are usually newlybuilt residences connected to the natural gas network. Otherwise, percentages over $20 \%$ are registered only in the urban area.

According to the all-country mean, $65.1 \%$ of the households have indoor bathroom, the European mean being of $95 \%$. Few houses in Romania benefit from this facility, only three out of five owners have at least one indoor bathroom. Eight of the Danube Valley communes situated in the neighborhoods of urban centers register over $50 \%$ at this indicator (Şendreni close to Galaţi city), or are tourist destinations (in the Danube Delta - Pardina, Mahmudia; in the mountain region and the Iron Gate Defile- Dubova, Pojejena, Şviniţa, Coronini, etc.). On the other hand, 14 communes (all in Olt County) have no bath-rooms (Cilieni, Gârcova, Giuvarăşti, Grojdiboju, Gura Padinii, Izbiceni, Orlea, Ştefan cel Mare, Tia Mare, Urzica, Vădastra, Vădăstriţa, Vişina and Vişina Nouă).

Out of the 720,357 conventional residences in the Romanian Danube Valley only 578,594 (80\%) have a indoor kitchen. The 2011 Population and Housing Census shows that the majority of local communities are far from meeting the EU living standards. Many rural households have outdoor kitchens. In the Romanian Danube Valley, disparities exist between the urban and the rural areas $(65 \%$ and $35 \%$, respectively). A number of 23 municipia and towns have a high score at this indicator (over 70\%), first in line standing Călăraşi, Olteniţa, Cernavodă, Brăila, Galaţi, Giurgiu and Drobeta-Turnu Severin (above 90\% each). In the rural area, the share of indoor kitchen households go from $20 \%$ in 


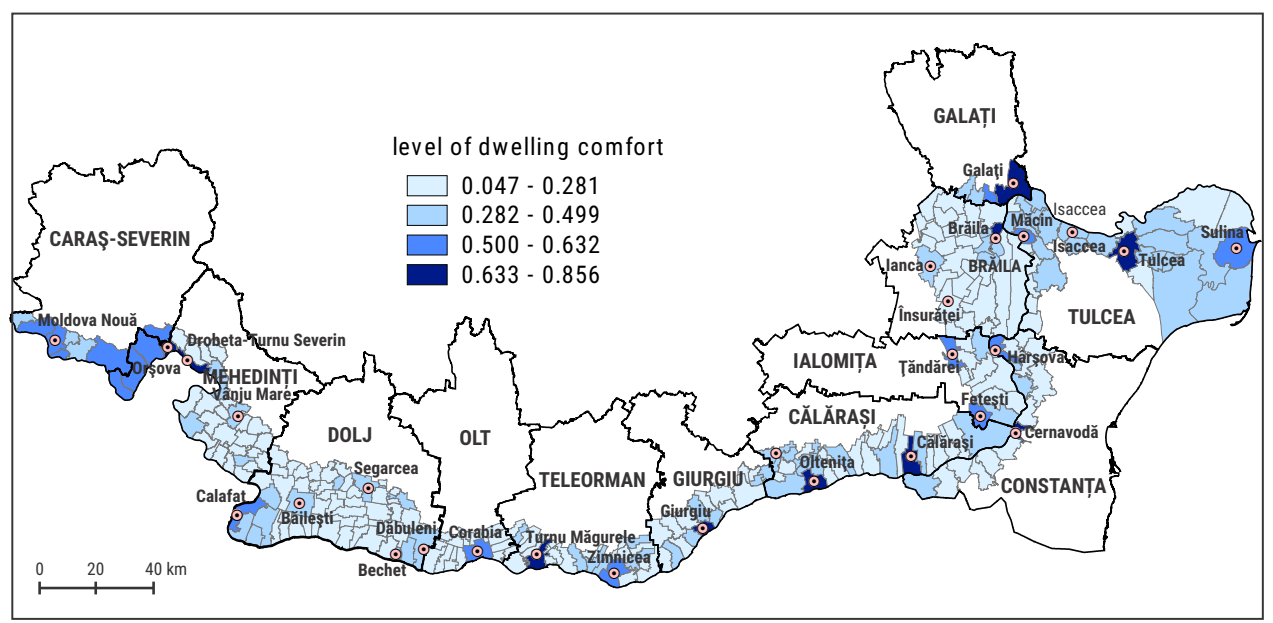

Figure 5. The dwelling comfort index- territorial disparities (DCI)

Source: 2011 Population and Housing Census and TempOnline statistical data processed and mapped

several communes of Brăila (Măraşu and Racoviţa) and Mehedinţi counties (Oprişor, Pristol and Gruia) to under 30\% in Tulcea and Giurgiu counties. Disparities between town and country-side are evidenced by very high values, similar to those registered in the previously-mentioned cities, namely in 15 communes of Giurgiu, Teleorman, Călăraşi and Galaţi counties.

The dwelling comfort index (DCI) shows variations between a minimum of 0.047 (Malu Commune, Giurgiu County), and a maximum of 0.856 (Galaţi Municipium, Galaţi County). Compared to the previous two indicators, all the values of this indicator are the highest, $10 \%$ of all the Danube Valley administrative units have an over 0.500 score. This category includes mostly the Danube Valley urban localities, but also o few communes close to large municipia (Şendreni near Galaţi), or discharging tourist activities (communes in the Iron Gate Defile and in the Danube Delta). In the lower part of the hierarchy of localities, the values of this indicator show settlements clustered over relatively extended areas in Dolj and Brăila counties, and in smaller areas of Teleorman, Giurgiu and Ialomiţa counties (Figure 5).

\section{The dwelling quality index (DQI)}

In order to outline territorial disparities in the quality of the Danube Valley rural dwelling stock, we proceeded to calculate and map out the dwelling quality index (DQI). With maximum values of 0.500-0.609, the Danube Valley residences have an average development level and only a few cities (Galaţi, Brăila, Drobeta-Turnu Severin and Tulcea) have a good score (Figure 6, Table 1).

In these four urban centres statistical indicators and secondary indexes register elevated values (number of residences in place and share of finished houses per total dwelling stock), with a record high for dwelling comfort (indoor drinking water, indoor connection to the sewerage network, indoor bathroom and kitchen, electricity, etc.). Medium dwelling quality is given by reduced living floor per inhabitant and per residence. 


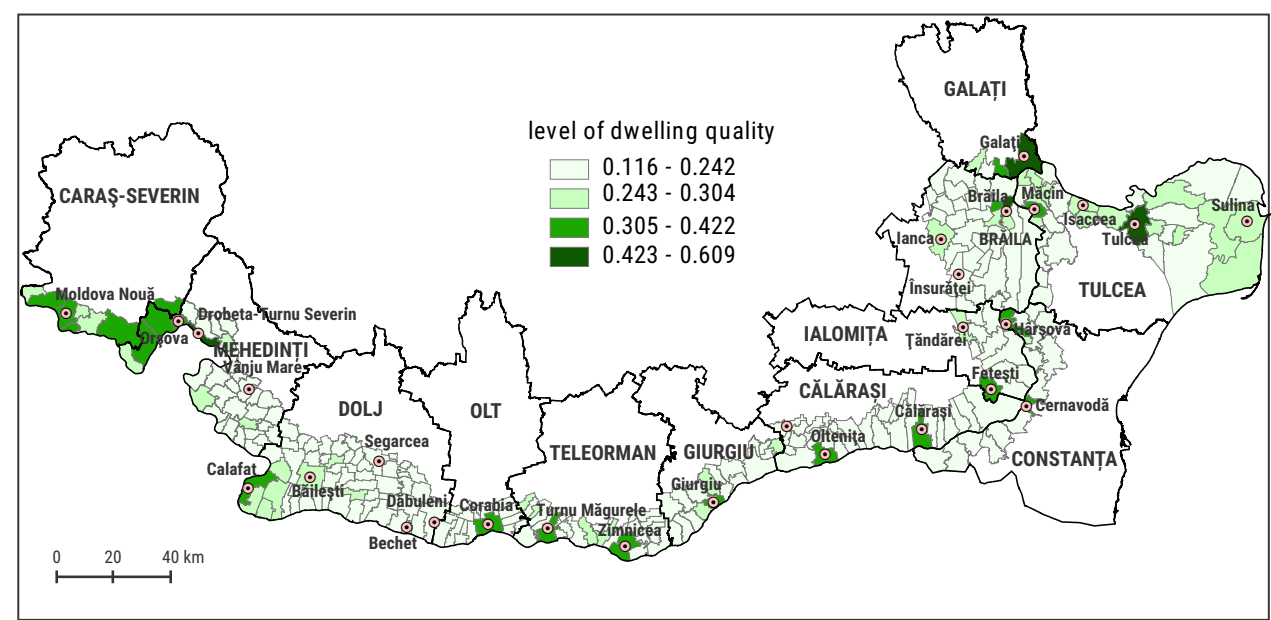

Figure 6. The dwelling quality index (DQI)

Source: 2011 Population and Housing Census and TempOnline statistical data processed and mapped

Table 1. The hierarchy of local administrative units in terms of secondary indexes and dwellings

\begin{tabular}{|c|c|c|c|c|c|c|c|c|}
\hline $\begin{array}{l}\mathbf{N} \\
0\end{array}$ & $\begin{array}{l}\text { Local } \\
\text { administrati } \\
\text { ve units } \\
\text { (LAU2) }\end{array}$ & DQI & $\begin{array}{l}\text { Local } \\
\text { administ } \\
\text { rative } \\
\text { units } \\
\text { (LAU2) }\end{array}$ & DSI & $\begin{array}{l}\text { Local } \\
\text { administ } \\
\text { rative } \\
\text { units } \\
\text { (LAU2) }\end{array}$ & DDI & $\begin{array}{l}\text { Local } \\
\text { administr } \\
\text { ative units } \\
\text { (LAU2) }\end{array}$ & DCI \\
\hline 1 & Galații & 0.609 & Galați & 0.500 & Carcaliu & 0.717 & Galați & 0.856 \\
\hline 2 & Brăila & 0.535 & Brăila & 0.351 & Goicea & 0.617 & $\begin{array}{l}\text { Drobeta- } \\
\text { Turnu } \\
\text { Severin }\end{array}$ & 0.848 \\
\hline 3 & $\begin{array}{l}\text { Drobeta- } \\
\text { Turnu } \\
\text { Severin }\end{array}$ & 0.529 & $\begin{array}{l}\text { Drobeta- } \\
\text { Turnu } \\
\text { Severin }\end{array}$ & 0.179 & Lunca & 0.580 & Brăila & 0.788 \\
\hline 4 & Tulcea & 0.500 & Tulcea & 0.148 & Tulcea & 0.579 & Tulcea & 0.774 \\
\hline 5 & Giurgiu & 0.422 & Călăraşi & 0.127 & $\begin{array}{l}\text { Drobeta- } \\
\text { Turnu } \\
\text { Severin }\end{array}$ & 0.559 & Giurgiu & 0.767 \\
\hline 6 & Călăraşi & 0.418 & Giurgiu & 0.122 & Pristol & 0.558 & Cernavodă & 0.757 \\
\hline 7 & Feteşti & 0.380 & Feteşti & 0.060 & Pojejena & 0.552 & Călăraşi & 0.756 \\
\hline 8 & Orşova & 0.379 & Şendreni & 0.056 & Văcăreni & 0.550 & Olteniţa & 0.739 \\
\hline 9 & Eşelniţa & 0.371 & $\begin{array}{l}\text { Turnu } \\
\text { Măgurele }\end{array}$ & 0.056 & $\begin{array}{l}\text { I.C. } \\
\text { Brătianu }\end{array}$ & 0.550 & Orşova & 0.698 \\
\hline $\begin{array}{l}1 \\
0\end{array}$ & Toplet & 0.368 & Cazaşu & 0.049 & Salcia & 0.542 & $\begin{array}{l}\text { Turnu } \\
\text { Măgurele }\end{array}$ & 0.686 \\
\hline
\end{tabular}

With the exception of the towns previously mentioned, the other administrative units, whether county-seat municipia, towns or communes, have under 0.500 dwelling quality index values meaning low and very low housing quality, most of them scoring between 0.422 and 0.300 . Very low housing quality $(0.116-$ 0.242) is seen in most communes of the Mehedinţi, Dolj, Giurgiu, Călăraşi and Brăila counties. Communes close to towns enjoy better dwelling quality than those lying far from the urban centres, yet still low enough, a situation existing 
also in the case of major Danube Valley cities (Galaţi, Brăila, Drobeta-Turnu Severin and Tulcea), but in small towns as well (the urban influence area of Calafat, Bechet and Olteniţa).

The Romanian housing model, shared with the other post-communist countries, was mainly determined by the historical pathway, especially by the communist one: a high share of home ownership (96.6\% in 2012 according to Living conditions in Europe), with a low proportion of homes owned with, a low share of renting and an almost insignificant fraction of social housing (Precupeţu and Precupețu, 2013). These features are specific also for the Romanian Danube valley, the features above mentioned involving a number of advantages, but also a series of issues, characterizing all Romanian counties, the Danubian ones included. The issues are related to the low level of dwelling quality, emerged from the difficulties of owners for proper maintenance of their purchased property (Marginean 2006 quoted by Precupeţu and Precupeţu, 2013).

The situation of dwellings' quality in Romanian Danube Valley is not very different from the national average one. In terms of low dwelling comfort (e.g. indoor drinking water, indoor connection to the sewerage network, indoor bathroom and kitchen), in the Romanian sector of Danube Valley are obvious the same disparities between the urban and rural dwellings and also between Danubian rural space and the whole Romanian countryside. The elements which offer unicity to Danubian dwellings are emerging from the physicalgeographical, historical and cultural backgrounds. The dominant natural component is the Danube Valley, which governs all natural and human systems and the floods are one of the most important physical-geographical factor, transforming radically dwelling-houses often destroying them completely. Also, historical and cultural characteristics personalise the dwellings from Romanian Danube Valley, among others, through the presence of certain ethnical groups (e.g. Lipovans and Russians in Danube Delta, Czechs and Serbians in Iron Gate Defile), knowing that the common elements resulting from the cohabitation of several ethnicities in the same habitat can be seen in the structure of the household, the planimetry of the actual dwelling, the materials and the construction techniques used (Majuru, 2011).

\section{Conclusions}

Inequalities characterized quality of dwellings in Romanian Danube Valley, especially in terms of differences between urban and rural areas. Generally, urban areas provide a relatively modern infrastructure with good access to utilities, whereas rural areas provide people with a much lower quality of housing. Here houses are frequently built with low endurance materials and there is limited or no access to utilities. Other disparities that characterize quality of dwellings are between small cities and big cities, neighborhoods with individual homes and those with blocks of apartments.

As a rule, the factors involved in dwelling quality are distinctively different in the urban and the rural. In the former case, it is small towns that are affected, while in the latter, it is the poor lowland regions where things are particularly serious. In the country-side, it is individual dwelling-houses that prevail and 
wherever collective housing exists, it provides little comfort. The recently built individual households, erected in the newly-expanded areas and in suburban communes, have high building costs (of the terrain as well) and quite excessive density. The collective dwellings are generally well-equipped. Specific problems in this case are obsoleteness of structure and installations, or the physical and moral wear of the house (finishes, sizing, structural layout, location, excessive density, high maintenance and functioning costs, or poor quality of indoor and outdoor spaces).

The household structure, building materials and type of construction differ with the geographical region and the cultural tradition. The scattered mountain villages (Banat Mountains and Iron Gate Gorge) dwellings are devoid of centralbased public utilities, access to community and daily amenities being a difficult matter, hence poor housing comfort. In the clustered lowland villages (of the Romanian Plain and the Danube Flood-plain) the dwelling stock is of poor quality and reduced life-time. Little access to resources (drinking water) and public utilities (gas network, sewerage system, etc.) downgrade the quality of the Danube Valley residential places. In general, the life-time of country-side houses lasts for one or two generations.

Ensuring adequate dwelling comfort means priority actions to expend the dwelling stock, enlarge the built-in area and optimize the living floor size, provide it with water, sewerage and heating facilities create thermal dwelling comfort and security. Future prospects have in view to extend drinking water supply and sewerage networks, make the distribution system more efficient and increase the number of people with access to drinking water. In the Danube Valley, the POS MEDIU contains several projects of drinking water supply to the population. Housing shortage in town is a capital problem felt especially by the young, income-low population; as important is also the degradation of the collective dwelling stock, because the population is short of money to maintain it properly. Rehabilitating or replacing a house raises major financial, economic and social problems. Providing the necessary housing facilities is again very difficult, especially in the poor rural areas where securing utilities is a difficult matter. Non-authorized, or unhealthy dwelling structures is as yet rather a local problem, but obviously tending to extend.

\section{Acknowledgements}

The research-work for this paper was made under the Institute of Geography's research plan (a priority research project of the Romanian Academy on the "Geographical Study of the Romanian Danube Valley").

\section{References}

Academia Română, Institutul de Geografie 2007, Romania. Historical-Geographical Atlas (România. Atlas istorico-geografic), $2^{\text {nd }}$ edition, Editura Academiei Române, Bucharest.

Alpopi, C 2007, 'Contextul european şi tendințe ale locuirii în România', 
Administrație şimanagement public, vol. 8, pp. 74-80.

Alpopi, C, Iacoboaea, C \& Stănescu, A 2014, 'Analysis of the Current Housing Situation in Romania in the European Context', Transylvanian Review of Administrative Sciences, vol. 43, pp. 5-24.

Antonescu, D 2014, 'Quantitative and qualitative aspects regarding housing in the European Union and Romania', Munich Personal RePEc Archive, viewed 10 May 2016, https://goo.gl/zmmrlF.

Council of Europe 2000, Principii directoare pentru Dezvoltarea teritorială durabilă a Continentului european, Conference of Ministers Responsible for Spatial/Regional Planning, C.E.M.A.T Hanovra.

Damian, N 2013, The Danube Delta geographical environment and social risk factors (Mediul geografic şi factorii de risc social din Delta Dunării), Editură Universitară, Bucharest.

Dan, AN 2003, 'Accesul la locuire în România astăzi', Calitatea Vieții, vol. 3-4, pp. 409-429.

Dan, AN 2005, 'Locuirea în România. Dreptul la locuire', Calitatea Vieții, vol. 16, no. 1-2, pp. 3-20

European Commission 2011, Panorama 37 Strategia UE pentru Regiunea Dunării. Eforturi unite în abordarea provocărilor comune, viewed 10 February 2016, https://goo.gl/CcGk.

European Commission 2013, Report from the Commissions to the European Parliament, the Council, The European Economic and Social Committee and the Committee of the Regions concerning the European Union Strategy for the Danube Region, European Commission, $\operatorname{COM}(2013)$ 181, Brussels.

European Union 2014, Living conditions in Europe, 2014, Eurostat, Luxembourg: Publications Office of the European Union, viewed 12 February 2015, https://goo.gl/ltW2wG.

Fondeville, N \& Ward, T 2009, 'The effects of the financial crisis on housing and the risk of poverty', Research note 3, viewed 5 February 2016, https://goo.gl/fdLY8t.

Gavriş, A 2011, Mari habitate urbane în București, Editură Universitară, Bucharest.

Heathcote, J, Violante, G \& Perri, F 2010, Inequality in times of crisis: Lessons from the past and a first look at the current recession, viewed 2 February 2010, VoxEU.org.

Intelligent Energy Europe Programme 2010, 'Promoting Solar Thermal Ordinances Project- ProSTO, 2008-2010', Newsletter no. 6.

Kabisch, S \& Grossmann, K 2013, 'Challenges for Large Housing Estates in Light of Population Decline and Ageing: Results of a Long-term Survey in East Germany', Habitat International, vol. 39, pp. 232-239.

Majuru, A 2012, Similitudini şi diferențe-fenomene ale coetnicităţii într-o zonă culturală (Studiu de caz: Dobrogea, viewed 12 February 2015, https://goo.gl/yRcqe1.

Marginean, I (ed.) 2006, Quality of life in Bulgaria and Romania, Office for Official Publications of the European Union, Luxembourg.

Ministerul Dezvoltării Regionale şi Administraţiei Publice 2014, Strategia de dezvoltare teritorială a României - Servicii elaborare studii în vederea implementării activităţilor proiectului cu titlul „Dezvoltarea de instrumente şi modele de planificare strategică teritorială pentru sprijinirea viitoarei perioade de programare post 2013, viewed 10 February 2016, https://goo.gl/QcAg7k.

Nae, M 2006, Geografia calităţii vieții urbane. Metode de analiză, Editură Universitară, Bucharest. 
Nae, M 2009, Bucureşti. Dezvoltarea urbană şi calitatea vieţii, Editură Universitară, Bucharest.

Precupețu, I \& Precupețu, M 2013, 'Growing inequalities and their impacts in Romania', GINI - Growing Inequalities' Impacts, viewed 10 February 2016, https://goo.gl/qTzMGc.

Vâlceanu, D \& Zulaica, L 2012, 'Indicele calităţii locuirii - instrument de evaluare a calității locuirii urbane', Urbanism. Arhitectură. Construcții, vol. 3, no. 4, pp. 45-56.

Vâlceanu, DG \& Tămîrjan, DG 2011, 'Calitatea condițiilor de locuire în România, în perioada post-aderare la UE', Urbanism. Arhitectura. Construcții, vol. 3, no. 2, pp. 35-50.

Vîrdol, D, Suditu, B, Dumitrache, L \& Vâlceanu, DG 2015, 'Dynamics of housing stock in Romania - between politics and policies', Human Geographies - Journal of Studies and Research in Human Geography, vol. 9, no. 2, pp. 207-223.

Voicu, B \& Voicu, M 2005, 'Accesul la utilități publice, în România', Revista Calitatea vieții, vol. 1-2, pp. 21-49.

Voicu, M 2008, 'Locuirea de calitate - parte a dezvoltării durabile', in I Marginean \& I Precupețu (eds), Calitatea vieții şi dezvoltarea durabilă, pp. 77-95, Editură Expert, Bucharest.

Zamfir, E, Preda, M \& Dan AN 2004, 'Surse ale excluziunii sociale în România', Revista de Asistență Socială, no. 3-4. 